OPEN ACCES

\title{
Low Concentration Platinum Nanoparticles Effectively Scavenge Reactive Oxygen Species in Rat Skeletal L6 Cells
}

\author{
Hidekazu Nakanishi ${ }^{1}$, Takeki Hamasaki ${ }^{2}$, Tomoya Kinjo ${ }^{1}$, Hanxu Yan ${ }^{1}$, Noboru Nakamichi ${ }^{2}$, Shigeru Kabayama ${ }^{3}$, Kiichiro Teruya ${ }^{1,2}$, Sanetaka \\ Shirahata ${ }^{1,2, *}$ \\ ${ }^{1}$ Division of Life Engineering, Graduate School of Systems Life Sciences, Kyushu University, 6-10-1 Hakozaki, Higashi-ku, Fukuoka 812-8581, \\ Japan \\ ${ }^{2}$ Department of Bioscience and Biotechnology, Faculty of Agriculture, Kyushu University, Fukuoka 812-8581, Japan \\ ${ }^{3}$ Nihon Trim Co. Ltd., 1-8-34 Oyodonaka, Kita-ku, Osaka 531-0076, Japan \\ * Corresponding author: Sanetaka Shirahata (sirahata@grt.kyushu-u.ac.jp) Tel/fax.: +81-92-642-3045/ +81-92-642-3052
}

\begin{abstract}
Prolonged exposure to excessive reactive oxygen species (ROS) increases risk factors for many diseases. Therefore, elimination of ROS as well as prevention of its production becomes critically important. In the present study, we evaluated the levels of cytotoxicity and ROS scavenging activity induced by synthetic platinum nanoparticles (PtNPs). Average size of synthesized PtNPs was 2.2 nm. Synthetic PtNPs were found to scavenge both induced and endogenous $\mathrm{H}_{2} \mathrm{O}_{2}$ significantly in L6 rat skeletal muscle cells at a very low concentration $\left(10^{-2} \mathrm{mg} / \mathrm{l}\right)$. To investigate the mechanism of action, the hierarchical oxidative stress model was used as an experimental model. To evaluate this possibility, we assessed glutathione concentration and gene levels of several antioxidant enzymes in PtNPs-treated $\left(10^{-3}-10 \mathrm{mg} / \mathrm{l}\right) \mathrm{L} 6$ cells. Reduced glutathione (GSH) was increased in the range of $10^{-3}-1 \mathrm{mg} / \mathrm{l}$, but not in the $10 \mathrm{mg} / \mathrm{PtNP}$-treated cells. The GSH/GSSG ratio increased significantly at $1 \mathrm{mg} / \mathrm{l}$ and decreased in the $10 \mathrm{mg} / 1 \mathrm{PtNP}-$ treated cells. Most of the gene transcripts for oxidative stress inducible heme oxygenase-1 (HO-1), glutathione reductase (GR), copper-zinc superoxide dismutase (CuZn-SOD), manganese superoxide dismutase (Mn-SOD), glutathione peroxidase (GPx), and catalase were increased significantly by PtNPs at $10^{-1}-10 \mathrm{mg} / \mathrm{l}$. Such upregulatory effects induced by synthetic PtNPs at high concentrations (1-10 mg/l) in L6 cells can be explained by the hierarchical oxidative stress model. However, the cellular responses induced by low levels $\left(10^{-3}-10^{-2} \mathrm{mg} / \mathrm{l}\right)$ of PtNPs could not be fully explained by this model.
\end{abstract}

Keywords: Platinum nanoparticle; Reactive oxygen species; Oxidative stress; Antioxidant enzyme; Gene transcript

Citation: H. Nakanishi, et al. Low Concentration Platinum Nanoparticles Effectively Scavenge Reactive Oxygen Species in Rat Skeletal L6 Cells. Nano Biomed. Eng. 2013, 5(2), 76-85.

DOI: $10.5101 /$ nbe.v5i2.p76-85.

\section{Introduction}

Oxidative stress becomes apparent when reactive oxygen species (ROS) production exceeds the antioxidative defense systems inherent to the cell [1]. Prolonged oxidative stress leads to various diseases caused by damage to intracellular macromolecules, such as lipids, proteins, and DNA [2-5]. Three ways to circumvent or reduce oxidative stress have been suggested. These are to avoid the ROS generating environment (e.g., excessive exposure to ultraviolet radiation); enhance inherent antioxidative activity; and ingest antioxidants rich foodstuffs. In particular, utilization of antioxidants absorbed from foodstuffs is the most suitable way because of their easy availability and thus constitutes a rigorous research area. However, to facilitate a therapeutic effect in counteracting excess ROS, this approach faces the problem of low bioavailability of antioxidative ingredients despite ingesting large amounts Nano Biomed. Eng. 2013, 5(2),76-85

of antioxidant-containing foods [6]. This is especially relevant in the brain because of the blood-brain barrier [7]. In contrast, accumulated antioxidants in the body are likely to be converted to prooxidants $[8,9]$. Therefore, the development of antioxidative agents that can efficiently control oxidative stress with limited consumption assure the maintenance of normal cellular homeostasis is highly anticipated.

One such prospective agent is metal nanoparticles because of their characteristic properties including optical, electrical, and high catalytic activities. These properties are valuable to applications in electrical equipment, chemistry, physics, biology, and medical science. Noble metal nanoparticles (NPs) are especially attractive because of their biocompatibility, surface activity, antioxidative activity, and plasmon resonance 
effects [10,11]. Gold nanoparticles (AuNPs) and platinum nanoparticles (PtNPs) are considered the most important noble metal nanoparticles in the field of biomaterials. AuNPs have been suggested to suppress inflammatory responses in IL-6 human hepatocytic cells [12]. PtNPs have been suggested to act as a catalyst in in vitro reduction reactions and possess negative surface charges giving rise to an electric repulsion among charged particles allowing them to be stably suspended in solution [13]. Previously, we reported that synthetic PtNPs (2-3 nm) could significantly scavenge ROS, such as superoxide anion radical $\left(\mathrm{O}_{2}^{-}\right)$, hydrogen peroxide $\left(\mathrm{H}_{2} \mathrm{O}_{2}\right)$ and hydroxyl radical $(\mathrm{OH} \cdot)$ in HeLa cells and in a hypoxanthine-xanthine oxidase system [14]. PtNPs are less cytotoxic because of their chemical stability and resistance to ionization compared with other metal nanoparticles $[15,16]$. A previous study has reported on the non-cytotoxic properties of PtNPs, of which $10^{-4}$ $10^{3} \mathrm{ng} / \mathrm{cm}^{2}\left(7.86 \times 10^{-7}-7.86 \mathrm{mg} / \mathrm{l}\right)$ of $20-100 \mathrm{~nm}$ PtNPs affected neither cellular metabolism nor cell death [17]. However, the data supporting the safety and biological antioxidative activity of PtNPs remain limited; hence, confirming the safety aspects of nanoparticles are critically important for future applications.

Although NPs at higher concentrations (3-400 mg/l) and larger sizes (5-100 nm) can cause oxidative stress leading to cytotoxicity, they also in certain conditions induce antioxidative enzymes responsible for cytoprotection [1821]. According to the hierarchical oxidative stress model, detoxification and antioxidative enzymes are induced via the NF-E2-related factor 2 (Nrf2)/antioxidant responsive element (ARE) pathway resulting from high oxidative stress conditions [22-24]. However, applicability of the model has not been tested on cellular responses induced by synthetic PtNPs. We used the L6 rat skeletal muscle cell system to further investigate the mechanisms of cytoprotective effects of PtNPs. In the present study, L6 cells were used because of their considerably high resting total glutathione level and related antioxidant enzymes [25]. Additionally, glutathione and other phase II detoxifying antioxidant enzymes regulated by the Nrf2/ARE pathway are activated by oxidative stress in endothelial and smooth muscle cells [26]. Moreover, NPs induce ROS to activate a pathway of MAPK-NFKB-Nrf2ARE-phase II enzymes and antioxidant enzyme gene expression, and this pathway has been shown to operate as a defense mechanism [18,24,26-28]. Therefore, we aimed to evaluate whether the cellular responses induced by synthetic PtNPs were consistent with the hierarchical oxidative stress model with an emphasis on antioxidative enzyme gene expression.

\section{Experimental Section}

\subsection{Materials}

Hydrogen hexachloroplatinate $\left(\mathrm{H}_{2} \mathrm{PtCl}_{6}\right)$, L-buthionine $\mathrm{S}$, R-sulfoximine (BSO), bis-chloroethylnitrosourea (BCNU), L-glutathione reduced (GSH), ethylene- diaminetetraacetic acid (EDTA) and N-acetyl-L-cysteine (NAC) were purchased from Sigma-Aldrich Japan (Tokyo, Japan). 2-(4-Iodophenyl)-3-(4-nitrophenyl)-3-(2,4disulfophenyl)-2H-tetrazolium monosodium salt (WST-1), 1-methoxy PMS and Cell Stain Hoechst 33342 solution were purchased from Dojindo Laboratories (Kumamoto, Japan). Hydrogen peroxide, Bes- $\mathrm{H}_{2} \mathrm{O}_{2}-\mathrm{AC}$, 5-fluoroorotic acid DMSO solution, polyoxyethylene 20 sorbitan monolaurate (Tween 20), oxidized L-glutathione (GSSG), o-phthalaldehyde (OPA), and N-ethylmaleimide (NEM) were purchased from Wako Pure Chemical Inc. (Tokyo, Japan). Amberlite EG-4-HG was purchased from Organo Corp. (Tokyo, Japan). Thunderbird SYBR qPCR Mix was purchased from Toyobo (Osaka, Japan). 3H-1,2-dithiole3-thione (D3T) was obtained from LKT Laboratories, Inc. (St. Paul, MN, USA). Sterile plastic dishes $(90 \mathrm{~mm}$ and $60 \mathrm{~mm}$ ) and culture plates (12-well and 96-well) were purchased from Greiner Bio-One Co., Ltd (Tokyo, Japan). Dulbecco's modified Eagle medium (DMEM) was from Nissui Pharmaceutical Co., Ltd. (Tokyo, Japan). Fetal bovine serum (FBS) was from Invitrogen Japan (Tokyo, Japan). Penicillin and streptomycin were obtained from Meiji Holdings Co., Ltd (Tokyo, Japan). All solutions were prepared with deionized water produced by a Milli-Q synthesis system (Milli-Q water, Merck Millipore, Tokyo, Japan). All other chemicals were of analytical reagent grade and obtained from Wako Pure Chemical Inc. (Tokyo, Japan).

\subsection{Preparation of PtNPs}

Strong reducing reagents, such as hydrazine monohydrate, and sodium tetrahydroborate, are usually used to prepare metal nanoparticles. Some of these reagents are toxic to living organisms when they are nanoparticle contaminants. From this point of view, citrate and ethanol are often used to prepare noble metal nanoparticles for biological applications. Therefore, we selected sodium citrate as a reducing reagent because of its safety, low cost, and ability to serve as a stabilizer during preparation $[29,30]$. PtNPs were synthesized by a modified citrate reduction method of $\mathrm{H}_{2} \mathrm{PtCl}_{6}$ as described before [14,31]. In brief, the solution containing the appropriate platinum complex (in a concentration equivalent to $2.62 \mathrm{~g}$ hydrogen hexachloroplatinate in $1000 \mathrm{ml}$ water) was brought to its boiling point, and $5 \mathrm{ml}$ of $20 \mathrm{wt} \%$ sodium citrate was added. The solution was then refluxed for $6 \mathrm{~h}$, during which time samples were taken to determine changes of absorbance at $600 \mathrm{~nm}$ using a spectrophotometer (UV-2450, Shimadzu, Kyoto, Japan). The reaction was considered complete when the absorbance reached a constant value. The solutions were demineralized by an Amberlite EG-4-HG ion-exchange resin. The concentration of PtNPs was determined by inductively coupled plasma mass spectrometry (ICP-MS, Agilent 7500, Agilent Technologies, CA, USA) at the Center for Advanced Instrumental Analysis, Kyushu University. The concentration of the synthesized PtNPs was adjusted to $100 \mathrm{mg} / \mathrm{l}$ and stored at $4^{\circ} \mathrm{C}$. The sizes of the PtNPs were 
analyzed by transmission electron microscopy (TEM; JEM 2000 FX, JEOL, Tokyo, Japan), and the sizes for PtNPs in the photograph were determined using freely available ImageJ 1.41 software downloaded at imagej.nih. gov/ij/download/.

\subsection{Cell cultures}

L6 rat skeletal muscle cells obtained from American Type Culture Collection (ATCC, Manassas, VA, USA) were cultured in DMEM supplemented with 10\% FBS, 100 units $/ \mathrm{ml}$ penicillin, and $100 \mu \mathrm{g} / \mathrm{ml}$ streptomycin in $10 \mathrm{~mm}$ culture dishes at $37^{\circ} \mathrm{C}$ in a humidified atmosphere with $5 \% \mathrm{CO}_{2}$. Undifferentiated myoblast cells were used in the present study.

\subsection{Cell viability assay}

Effects of PtNPs on L6 cells were evaluated by WST1 assay kit following the manufacturer's instructions. L6 cells were seeded in 96-well plates at a density of $5.0 \times 10^{3}$ cells/well in $100 \mu \mathrm{l}$ culture medium and incubated in a humidified atmosphere with $5 \% \mathrm{CO}_{2}$ at $37^{\circ} \mathrm{C}$ for $24 \mathrm{~h}$. Culture medium was then aspirated, and the wells were washed twice with PBS buffer. Each well was filled with $100 \mu \mathrm{l}$ medium containing PtNPs at concentrations of 0-10 $\mathrm{mg} / \mathrm{l}$ and incubated for $24 \mathrm{~h}$. As a negative control group, three wells were filled with cells in DMEM medium without PtNPs. After a $2 \mathrm{~h}$ cultivation, the wells were washed twice with PBS buffer, and $100 \mu 1$ DMEM with WST-1 $(500 \mu \mathrm{M})$ and PMS $(20 \mu \mathrm{M})$ were added. After a $1 \mathrm{~h}$ incubation, absorbance of each well was measured at $450 \mathrm{~nm}$ using a microplate reader (Tecan Group Ltd., Männedorf, Switzerland).

\subsection{LDH measurement}

LDH leakage was measured using a LDH Kit (Wako Pure Chemical Inc., Tokyo, Japan) closely following the manufacturer's instructions. Briefly, L6 cells were seeded in 96 -well plates at a density of $5.0 \times 10^{3}$ cells/well in $50 \mu \mathrm{l}$ culture medium and incubated in a humidified atmosphere with $5 \% \mathrm{CO}_{2}$ at $37^{\circ} \mathrm{C}$ for $24 \mathrm{~h}$. Several concentrations of PtNPs were then added to each well and incubated at $37^{\circ} \mathrm{C}$ for $2 \mathrm{~h}$. For the positive control, cells were incubated with medium containing $0.1 \%(\mathrm{w} / \mathrm{v})$ Tween 20 and the resulting LDH level released was set as $100 \%$. Released LDH was measured at $595 \mathrm{~nm}$, and relative LDH release is defined as the ratio of released LDH by PtNPs compared with that of Tween 20. Less than $10 \%$ LDH release compares to Tween 20 was regarded as nontoxic to L6 cells based on the criterion [32].

\subsection{Assessment of intracellular ROS}

L6 cells were seeded in 96-well plate at a density of $5.0 \times 10^{3}$ cells/well in $100 \mu \mathrm{l}$ culture medium and incubated at $37^{\circ} \mathrm{C}$ for $24 \mathrm{~h}$. Subsequently, culture medium was washed twice with PBS and replaced by $100 \mu \mathrm{l}$ medium containing PtNPs at $0-10 \mathrm{mg} / 1$ and incubated for $2 \mathrm{~h}$. After a $2 \mathrm{~h}$ exposure, the wells were washed twice with PBS and incubated with $100 \mu \mathrm{l} 5 \mu \mathrm{M}$ Bes- $\mathrm{H}_{2} \mathrm{O}_{2}$-AC for
$30 \mathrm{~min}$ and $10 \mu \mathrm{l} 1 \mu \mathrm{M}$ Hoechst 33342 for $15 \mathrm{~min}$. The relative fluorescence intensity of $\mathrm{Bes}-\mathrm{H}_{2} \mathrm{O}_{2}-\mathrm{AC}$ indicating intracellular $\mathrm{H}_{2} \mathrm{O}_{2}$ was determined by IN Cell Analyzer 1000 (GE Healthcare, Tokyo, Japan) with an excitation at $480 \mathrm{~nm}$ and an emission at $535 \mathrm{~nm}$. To count the cell number, Hoechst 33342 was used for nuclei staining, and fluorescence was measured with an excitation at $352 \mathrm{~nm}$ and an emission at $461 \mathrm{~nm}$.

\subsection{Measurement of GSH and GSSG content}

Cellular GSH contents were measured by a modified method that is specific for the determination of GSH at pH 8.0 [33,34]. In brief, L6 cells were seeded in 12-well plates at a density of $1.0 \times 10^{5}$ cells/well in $1 \mathrm{ml}$ culture medium and incubated at $37^{\circ} \mathrm{C}$ for $24 \mathrm{~h}$. Afterward, culture medium was washed twice with $\mathrm{PBS}$ and replaced by $1 \mathrm{ml}$ of PtNP-containing medium at $0-10 \mathrm{mg} / \mathrm{l}$ and incubated for $2 \mathrm{~h}$. After a $2 \mathrm{~h}$ exposure, the wells were washed twice with PBS buffer, and cells were suspended in DMEM. A cell suspension was centrifuged at 250 $\times \mathrm{g}$ for $5 \mathrm{~min}$. The cell pellets were washed with PBS buffer. To the cell pellet, $2 \mu 125 \%$ metaphosphoric acid and $4 \mu 1400 \mathrm{mM}$ sodium phosphatase buffer containing $5 \mathrm{mM}$ EDTA at $\mathrm{pH} 8.0$ were added, and the cells were homogenized by ultrasonication on ice. After homogenization, the samples were centrifuged at 13,000 $\times \mathrm{g}$ for $30 \mathrm{~min}$. The supernatant was diluted 10 -fold with PBS, and $5 \mu \mathrm{l}$ of the diluted sample was incubated with $10 \mu \mathrm{l}$ of o-phthaldialdehyde $(0.1 \%$ in methanol) and 137 $\mu l$ phosphatase buffer for $15 \mathrm{~min}$ at room temperature. Fluorescence was read in a fluorescence spectrometer (F2500, Hitachi, Japan) at an excitation wavelength of 350 $\mathrm{nm}$ and emission wavelength of $420 \mathrm{~nm}$. Cellular GSH content was expressed as nmol GSH/mg cellular protein. Cellular protein was analyzed by the BCA method using a Microplate $\mathrm{BCA}^{\mathrm{TM}}$ assay kit (Thermo Scientific, Ill, USA). The supernatant obtained for GSH measurement as above mentioned was treated with $1 \mu 100 \mathrm{mM} \mathrm{NEM}$ for $30 \mathrm{~min}$ at room temperature to prevent the oxidation of GSH to GSSG, and cellular GSSG contents were measured at $\mathrm{pH} 12.0$ because the conversion of GSH to GSSG was negligible [33]. The absorbance and emission spectra for the OPT-GSSG reaction were equivalent to that of GSH.

\subsection{Quantitative reverse transcription polymerase chain reaction (qRT-PCR)}

Total RNA was isolated from variously treated L6 cells using a High Pure RNA Isolation Kit (Roche Diagnostics, Tokyo, Japan) following the manufacturer's instructions. Complementary DNA (cDNA) was synthesized using a ReverTra Ace qPCR RT Kit (Toyobo, Osaka, Japan) following the manufacturer's protocol. qRT-PCR was performed using Thunderbird SYBR qPCR Mix (Toyobo, Osaka, Japan) and a Thermal Cycler Dice Real-Time System TP-800 (Takara Bio Inc., Shiga, Japan). PCR amplification began with $10 \mathrm{~s}$ denaturation step at $95^{\circ} \mathrm{C}$ and then 40 cycles of denaturation at $95^{\circ} \mathrm{C}$ for $5 \mathrm{~s}$, 
Table 1 List of PCR primers.

\begin{tabular}{lclc} 
genes & F/R & sequences & sourse \\
\hline GAPDH & F & 5'-CTTCACCACCATGGAGAAGG-3' & [59] \\
& R & 5'-CTTACTCCTTGGAGGCCAT-3' & \\
\hline GR & F & 5'-GGGCAAAGAAGATTCCAGGTT-3' & \multirow{2}{*}{ [60] } \\
& R & 5'-GGACGGCTTCATCTTCAGTGA-3' & \\
\hline HO-1 & F & 5'-CTGGAAGAGGAGATAGAGCGAA-3' & [61] \\
& R & 5'-TCTTAGCCTCTTCTGTCACCCT-3' & \\
\hline Mn-SOD & F & 5'-GACCTGCCTTACGACTATG-3' & \multirow{2}{*}{ [62] } \\
\hline Cu/Zn-SOD & R & 5'-TACTTCTCCTCGGTGACG-3' & \\
\hline Catalase & F & 5'-CGAGCATGGGTTCCATGTC-3' & \multirow{2}{*}{ [63] } \\
\hline GPx & R & 5'-CTGGACCGCCATGTTCTTAG-3' & \\
\hline & F & 5'-ACAACTCCCAGAAGCCTAAGAATG-3' & [64] \\
\hline
\end{tabular}

Abbreviations: Forward (F), Reverse (R), glyceraldehyde-3-phosphate dehydrogenase(GAPDH), Glutathione Reductase (GR), Heme oxygenase 1 (HO-1), manganese superoxide dismutase (Mn-SOD), copper-zinc superoxide dismutase (Cu/Zn-SOD), glutathione peroxidase (GPx).

annealing at $55^{\circ} \mathrm{C}$ for $20 \mathrm{~s}$, and extension at $72^{\circ} \mathrm{C}$ for $20 \mathrm{~s}$. The samples were analyzed in triplicate, and the expression levels of each gene target were normalized to the corresponding glyceraldehyde-3-phosphate dehydrogenase (GAPDH) level. The PCR primer sequences are listed in Table 1.

\subsection{Statistical analysis}

Three independent replicates were conducted for all experiments. Data are presented as the mean \pm standard deviation (SD) of three independent experiments. Statistical significance was determined by two-tailed Student's $t$-test, and $p$ value of $<0.05$ was considered significant.

\section{Results and Discussion}

\subsection{Particle size estimation}

The sizes of the synthetic PtNPs were measured by TEM. Particle sizes within a designated size range from 0.5 to $4.0 \mathrm{~nm}$ in $0.5 \mathrm{~nm}$ increments revealed a distribution shown in Fig. 1b. From these data, the mean size of the

(a)

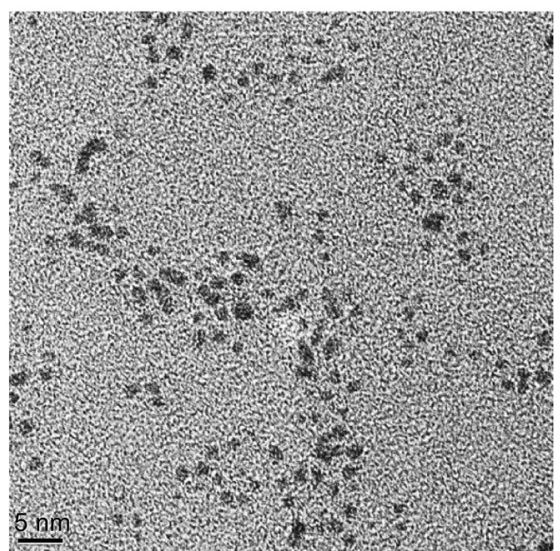

synthetic PtNPs was determined to be $2.2 \mathrm{~nm}$, which was advantageous because smaller NPs should be more efficiently taken up by the cells [35].

\subsection{Cytotoxity}

The toxic effects of metal nanoparticles have been well studied (14,17,36-39). Because of these undesirable effects, the cytotoxicity of the presently synthesized $2.2 \mathrm{~nm}$ PtNPs should be evaluated prior to their use in biological applications. Therefore, we measured the cytotoxicity of the $2.2 \mathrm{~nm}$ PtNPs.

The WST-1 assay was selected to assess the modulation of cellular mitochondrial activity. L6 cells were treated with various concentrations of PtNPs. PtNP concentrations between $10^{-3}$ to $10 \mathrm{mg} / 1 \mathrm{did}$ not exhibit any cytotoxic effect compared with the untreated control (Fig. 2a). Additionally, we used $\mathrm{H}_{2} \mathrm{O}_{2}$ as a positive control. Cell viability was reduced to approximately $80 \%$ with $200 \mu \mathrm{M}$ and $40 \%$ with $400 \mu \mathrm{M} \mathrm{H}_{2} \mathrm{O}_{2}$, respectively $(\stackrel{\#}{p}<0.01$, Fig. 2a). PtNPs are freely dispersed in solution

(b)

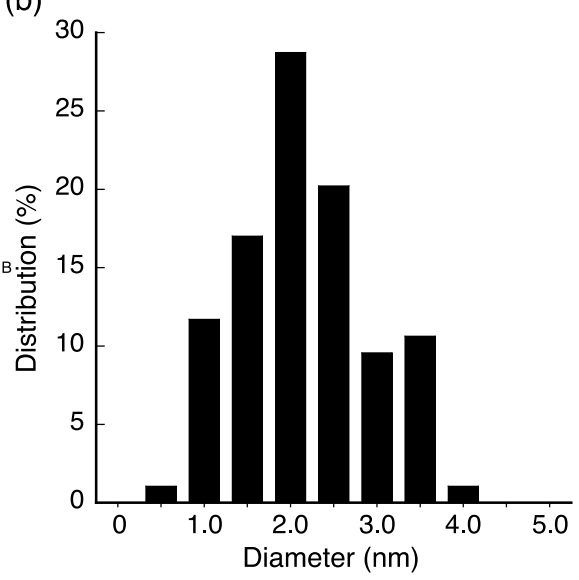

Fig. 1 (a) TEM image of PtNPs. (b) Ninety-four PtNPs were randomly chosen from the images to determine average particle sizes as the basis for the size distribution graph. 
http://nanobe.org
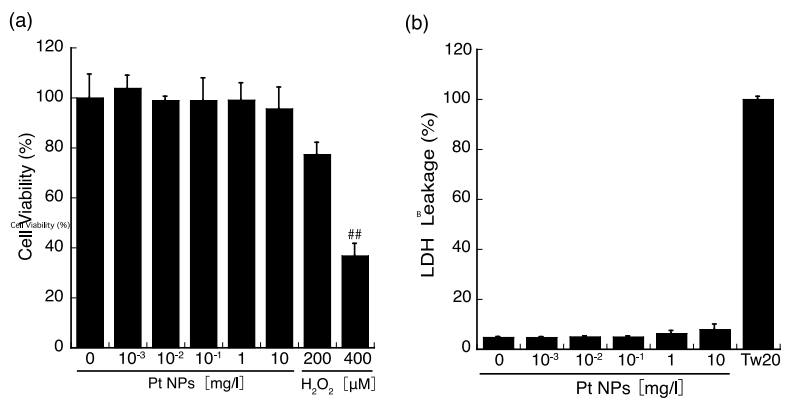

Fig. 2 Cytotoxicity assays for the synthetic PtNPs. (a) Viable cells were determined using the WST-1 assay kit after incubating L6 cells with the medium containing 10\% FBS and various concentrations of PtNPs for $24 \mathrm{~h}$. Pound marks denote significant difference from the untreated control cells $\left({ }^{\#} \mathrm{P}<0.01\right)$. (b) LDH leakage was measured using an LDH assay kit after incubating L6 cells with various concentrations of PtNPs for $2 \mathrm{~h}$.

and may affect cells via contact with and attachment to the cell surface, which can cause membrane injury. To assess this possibility, we used the LDH assay system because the loss of intracellular $\mathrm{LDH}$ and its release into culture medium is an indicator of irreversible cell death due to cell membrane damage. L6 cells were treated as described with various concentrations of PtNPs. PtNP concentrations between $10^{-3}$ to $10 \mathrm{mg} / \mathrm{l}$ did not exhibit significant LDH release $(<8 \%$ ) (Fig. $2 b)$, although the release of $\mathrm{LDH}$ did tend to increase as the PtNP concentration approached $10 \mathrm{mg} / \mathrm{l}$. In this assay system, we used Tween 20 as the positive control, and the released $\mathrm{LDH}$ was set to $100 \%$. For the interpretation of these results, we adopted the criterion used in a previous report whereby PtNPs are defined as non-toxic to the cell when released LDH is less than $10 \%$ of the control value [32]. PtNPs at less than $10 \mathrm{mg} / 1$ concentration did not exhibit any cytotoxic effect on L6 cells (Fig. 2b). Present results support previous findings that 2-3 nm synthetic PtNPs up to $50 \mathrm{mg} / \mathrm{l}$ are non-toxic to normal and cancer cell lines [14]; $10 \mathrm{mg} / \mathrm{l}$ of 5 to $8 \mathrm{~nm}$ PtNPs did not reduce the cell viability of either the human embryonic lung cell line (IMR-90) or the human glioma cell line (U251) [36]. PtNPs are regarded as less cytotoxic compared with other NPs in part because of their low ionization tendency. PtNPs have been shown to have no adverse effect on cell growth even at relatively higher concentrations (10$50 \mathrm{mg} / \mathrm{l}$ ) [14]. Because of these characteristics, little cytotoxicity should be induced by PtNPs at concentrations less than $10 \mathrm{mg} / \mathrm{l}$.

\subsection{ROS scavenging ability of PtNPs}

The majority of NPs cause cytotoxicity by oxidative stress $[37,38]$. We observed that the PtNPs used in the present study had a tendency to show slight LDH leakage at $10 \mathrm{mg} / \mathrm{l}$ (Fig. 2). In addition, cytotoxicity was induced by PtNP concentrations greater than $20 \mathrm{mg} / \mathrm{l}$, and pronounced cytotoxicity was induced by concentrations greater than $100 \mathrm{mg} / 1$ [36]. Such cytotoxicity induced by high PtNP concentrations may be caused by physical injury of the cell [39] and cytotoxic effects via partially ionized PtNPs [17,38]. Although cytotoxicity caused by most of the NPs is accompanied by increased ROS levels, PtNPs are an exceptional material because they do not increase ROS levels [36,40,41]. To evaluate the correlation between cytotoxicity as above observed and intracellular ROS levels, we performed a ROS scavenging assay using synthetic PtNPs. To investigate the effect of PtNPs on L6 cells, the relative amount of intracellular $\mathrm{H}_{2} \mathrm{O}_{2}$ was measured with a Bes- $\mathrm{H}_{2} \mathrm{O}_{2}-\mathrm{AC}$ fluorescent probe. This probe is designed to specifically detect intracellular $\mathrm{H}_{2} \mathrm{O}_{2}$, and its specificity is superior to that of the commonly used $2{ }^{\prime}, 7^{\prime}$-dichlorodihydrofluorescein diacetate [42]. PtNPs at six concentrations $\left(0,10^{-3}\right.$, $10^{-2}, 10^{-1}, 1$, and $\left.10 \mathrm{mg} / \mathrm{l}\right)$ were exposed to L6 cells for 2 $\mathrm{h}$, and intracellular ROS levels were measured using an IN Cell Analyzer. The relative fluorescence intensities of PtNP-treated L6 cells decreased significantly in a dosedependent manner with a PtNP concentration range between $10^{-2}$ to $1 \mathrm{mg} / 1\left({ }^{\# \#} \mathrm{p}<0.01\right.$, Fig. 3a). Surprisingly, PtNPs at a very low concentration $\left(10^{-2} \mathrm{mg} / \mathrm{l}\right)$ exhibited significant intracellular ROS scavenging activity, and ROS scavenging activity was observed even at $10^{-3} \mathrm{mg} /$ 1. To more thoroughly examine the scavenging ability of PtNPs, we used menadione to induce the ROS, especially $\mathrm{H}_{2} \mathrm{O}_{2}$, and evaluated the ROS scavenging activity of $10^{-2}$ $\mathrm{mg} / \mathrm{l} \mathrm{PtNPs}$ under excess ROS conditions. As shown in Fig. 3b, the Bes- $\mathrm{H}_{2} \mathrm{O}_{2}$-AC fluorescent probe level without these three components was set to $100 \%$ and designated as the absolute control. The relative fluorescence level incubated with DMSO (control experiment) alone increased significantly to $150 \%\left({ }^{* *} \mathrm{p}<0.01\right)$ compared with that of the absolute control. The relative fluorescence level incubated with DMSO and menadione increased significantly to $240 \%\left({ }^{* *} \mathrm{p}<0.01\right)$ and this was designated as the positive control. From the positive control, the relative fluorescence level significantly decreased to $55 \%$ with the addition of $10^{-2} \mathrm{mg} / 1$ PtNPs $\left({ }^{\#} \mathrm{p}<0.01\right)$. NAC alone with or without the other two components decreased endogenous $\mathrm{H}_{2} \mathrm{O}_{2}$ level significantly compared with that of the absolute $\left({ }^{\# \#} \mathrm{p}<0.01\right)$ and positive $\left({ }^{\# \#} \mathrm{p}<0.01\right)$ controls. These controls confirmed that this assay performed properly. Under these conditions, $10^{-2} \mathrm{mg} / \mathrm{l}$ PtNPs was found to scavenge intracellularly induced $\mathrm{H}_{2} \mathrm{O}_{2}$. PtNPs at higher concentrations $\left(10^{-1}-10 \mathrm{mg} / \mathrm{l}\right)$ and even at a very low concentration $\left(10^{-2} \mathrm{mg} / \mathrm{l}\right)$ were confirmed to scavenge endogenous as well as induced intracellular $\mathrm{H}_{2} \mathrm{O}_{2}$ significantly.

Intracellular ROS levels are thought to result from a primary response to internalized nanoparticles leading to decreased cell viability [43]. Thus, the suppression of excess ROS is of prime importance for cell survival. In this regard, our data suggested that PtNPs scavenge ROS in a dose-dependent manner from $10^{-3}$ to $10 \mathrm{mg} / 1$ in L6 cells. Notably, a very low level $\left(10^{-2} \mathrm{mg} / \mathrm{l}\right)$ of PtNPs could significantly scavenge ROS. Although a strong $\mathrm{O}^{2-}$ but not $\mathrm{H}_{2} \mathrm{O}_{2}$ scavenging ability of PtNPs has been reported, the concentration used was $2 \mathrm{mg} / \mathrm{l}(10 \mu \mathrm{M})$, and they did not examine concentrations less than $2 \mathrm{mg} / 1$ [41]. To our best knowledge, there is no report similar to our present 
(a)
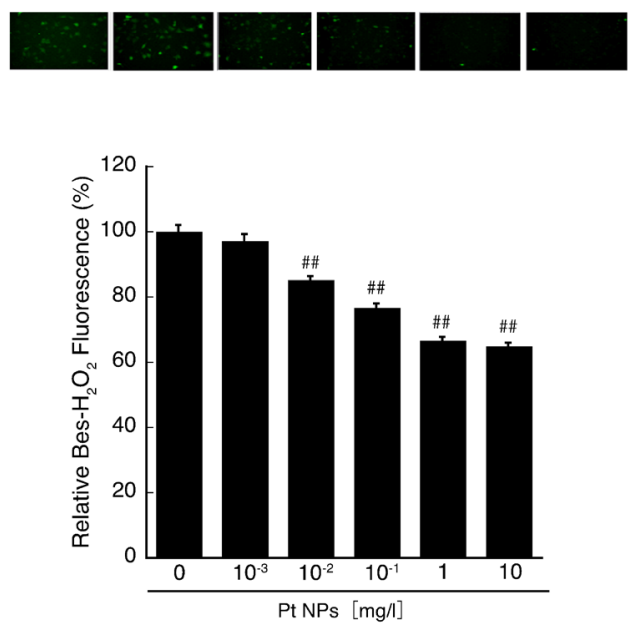

(b)

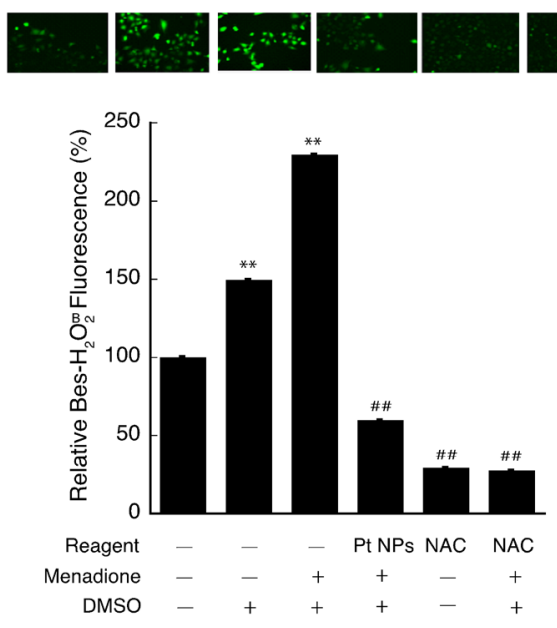

Fig. 3 ROS scavenging ability of PtNPs. (a) Scavenging effect of PtNPs on intracellular intrinsic $\mathrm{H}_{2} \mathrm{O}_{2}$. The fluorescence intensity of Bes$\mathrm{H}_{2} \mathrm{O}_{2}$-AC was indicative of the intracellular intrinsic $\mathrm{H}_{2} \mathrm{O}_{2}$ level per cell and determined by an IN Cell Analyzer. Pound marks denote significant difference from the untreated control cells $\left({ }^{\#} \mathrm{P}<0.01\right)$. Representative photographs of $\mathrm{Bes}-\mathrm{H}_{2} \mathrm{O}_{2}$ - AC detected fluorescent cells are shown above the graph, and the photograph on the left corresponds to the control bar at $0 \mathrm{mg} / \mathrm{l} \mathrm{PtNPs}$ in the graph. The other photographs correspond to bars at $10^{-3}$ to $10 \mathrm{mg} / 1$ PtNPs. (b) ROS scavenging ability of PtNPs pretreated with menadione. Each reaction cocktail shown under the graph was denoted by "+" for the addition of DMSO, menadione, PtNPs or NAC, and "--" denotes the lack of these components. Asterisks represent significant differences of the DMSO with or without menadione-treated cells compared with the untreated control cells (all “-", ${ }^{* *} \mathrm{P}<0.01$ ). Pound marks represent significant differences of the fluorescence intensities of menadione/DMSO/PtNP- or NAC-treated cells from that of the menadione/DMSO-treated cells $\left({ }^{\# \prime} \mathrm{P}<0.01\right)$. Representative photographs of $\mathrm{Bes}-\mathrm{H}_{2} \mathrm{O}_{2}-\mathrm{AC}$ detected fluorescent cells are shown above the graph, and the photograph on the left corresponds to the control bar in the graph without additives. The other photographs correspond to the bars with each treatment.

study that demonstrates ROS scavenging activity at these low concentrations. The mechanisms of intracellular ROS scavenging activity of PtNPs are unclear. Similar to inducing antioxidative enzymes, PtNPs are proposed to scavenge ROS directly or indirectly. Therefore, we performed additional experiments to determine the mechanism of ROS scavenging activity.

\subsection{Cellular GSH and GSSG content affected by PtNPs}

In an effort to identify the relevant ROS scavenging mechanism, we considered whether the hierarchical oxidative stress model is applicable to cellular responses following PtNP treatment [22,23]. The model is based on the 4-zones of oxidative stress levels residing between high GSH/GSSG ratio (low oxidative stress) and low GSH/GSSG ratio (high oxidative stress). Thus, in cells at a normal oxidant state, ROS are produced minimally in the mitochondria, which are readily neutralized by cellular defense systems, such as GSH and antioxidant enzymes. In the next zone, termed Tier 1 with a slightly increased oxidative stress level, cells respond to induce detoxification enzymes, such as heme oxygenases, and antioxidative enzymes, such as glutathione reductase, glutathione peroxidase, superoxide dismutase, catalase, and others via the Nrf2-ARE pathway. Incidentally, a higher oxidative stress zone, termed Tier 2, is believed to induce an inflammatory response activating NF- $\kappa \mathrm{B}$ and MAPK signaling pathways. The highest oxidative stress zone, termed Tire 3, causes cytotoxicity via mitochondrial perturbation [22-24]. Cellular responses to various NPs follow the hierarchical oxidative stress model [18]. Thus,
PtNPs synthesized in the present study are anticipated to exert an effect in accordance with this model and may induce antioxidative defense systems in L6 cells.

To determine whether PtNPs affect cellular GSH level, L6 cells were treated with increasing concentrations of PtNPs $\left(0,10^{-3}, 10^{-2}, 10^{-1}, 1\right.$ and $\left.10 \mathrm{mg} / \mathrm{l}\right)$, D3T, BSO and BCNU for $2 \mathrm{~h}$ followed by the measurement of intracellular GSH concentrations as described in the Materials and Methods section. DMSO, D3T, BCNU, and BSO were used as controls. The cells treated with these reagents exhibited GSH responses as expected. Therefore, increased GSH levels obtained after PtNP treatment are considered significant results.

Fig. 4a demonstrates that GSH levels in the $10^{-3}$, $10^{-2}, 10^{-1}$ and $1 \mathrm{mg} / 1 \mathrm{PtNP}$-treated L6 cells increased significantly without concentration dependency compared with that of the untreated control cells $\left({ }^{* *} \mathrm{p}<0.01\right)$. Such elevated GSH levels are expected to act on ROS directly, thereby protecting the cells from oxidative stress $[44,45]$. The level of intracellular GSH induced by $10 \mathrm{mg} / 1$ was similar to that of the control cells. As shown in Fig. 4b, GSSG levels were also measured using cell extracts that were prepared for GSH measurement. The GSSG levels of L6 cells treated with $10^{-3}$ to $1 \mathrm{mg} / 1$ PtNPs could not detect a significant effect compared with that of the untreated control cells. However, the GSSG levels of $10 \mathrm{mg} / 1 \mathrm{PtNP}-$ treated L6 cells increased significantly compared with that of the untreated control cells $\left({ }^{*} p<0.05\right)$. DMSO and BSO treatment slightly reduced GSSG levels, whereas D3T slightly elevated GSSG levels. BCNU treatment, in contrast, increased GSSG levels significantly $\left({ }^{*} \mathrm{p}<0.05\right)$. 
(a)

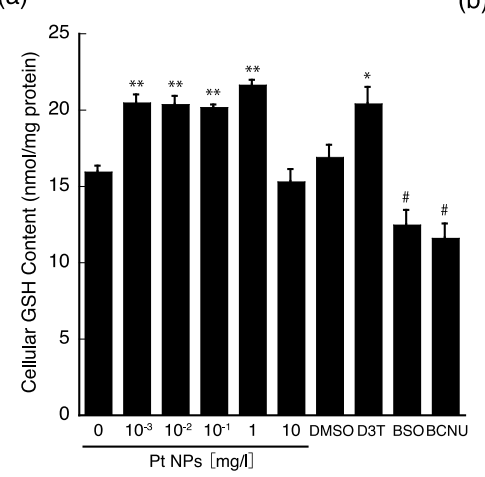

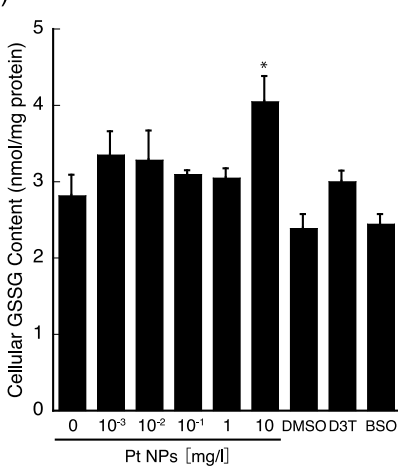

(c)

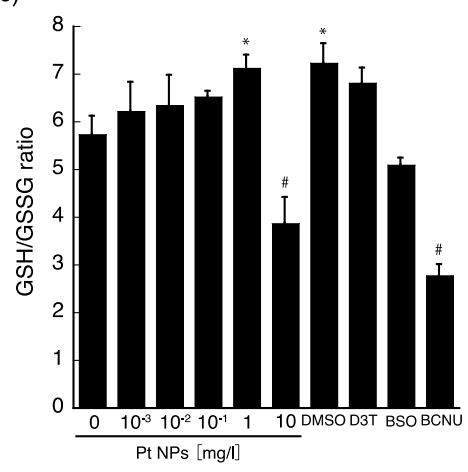

Fig. 4 Measurements of cellular GSH and GSSG content in L6 cells. (a) Cellular GSH content was determined by a published method [33] and expressed as nmol GSH/mg protein in which cellular protein content was determined by the BCA method. (b) Cellular GSSG content was masked by NEM and determined by a published method [33]. (c) GSH/GSSG ratios were determined using data obtained in (a) and (b). Asterisks and pound signs denote significant differences from the untreated control cells ( $\left.{ }^{*} \mathrm{P}<0.05,{ }^{* *} \mathrm{P}<0.01,{ }^{*} \mathrm{P}<0.05\right)$.

Using the data for GSH and GSSG, we calculated the GSH/GSSG ratio as shown in Fig. 4c. As a result, the GSH/GSSG ratio was found to increase significantly in the $1 \mathrm{mg} / \mathrm{l}$ PtNP-treated cells and decreased significantly at $10 \mathrm{mg} / \mathrm{l}$. Because we observed that LDH leakage was slightly increased in the LDH leakage assay, oxidative stress was assumed to be induced at $10 \mathrm{mg} / 1 \mathrm{PtNP}$. Because of this stress, increased GSH levels induced by PtNPs were converted through an oxidization reaction to increased GSSG levels and consequently reduced the GSH/GSSG ratio. In contrast, relative oxidative stress induced by PtNP concentrations below $1 \mathrm{mg} / 1$ is considered too weak to consume intrinsic GSH, thereby the GSH level is increased. This assumption appears to agree with the stress levels between Tier 1 and Tier 2 in the hierarchical oxidative stress model. However, the consistent reduction of intracellular ROS caused by PtNP concentrations from $10^{-3} \mathrm{mg} / 1$ to $10 \mathrm{mg} / 1$ would suggest an alternative mechanism that is different from the hierarchical oxidative stress model.

\subsection{Several antioxidative protein mRNAs are upregulated by PtNPs}

To evaluate our hypothesis, we determined antioxidative enzyme gene expression levels. We performed a series of qRT-PCR measurements by first evaluating GR transcript levels. L6 cells were treated for $2 \mathrm{~h}$ with increasing concentrations of PtNPs $\left(0,10^{-3}, 10^{-2}, 10^{-1}\right.$, 1 , and $10 \mathrm{mg} / 1)$. mRNA levels were determined, and the gene expression levels of antioxidative enzymerelated genes were investigated by RT-PCR. As shown in Fig. 5a, GR transcript levels were slightly increased when treated at $10^{-3}$ to $10^{-2} \mathrm{mg} / 1$. In particular, $1 \mathrm{mg} /$ 1 and $10 \mathrm{mg} / 1$ of PtNP-treated cells increased 3.1- and 3.5-fold, respectively. Likewise, we evaluated other antioxidative enzyme gene expression levels. HO1 , the marker for cellular oxidative stress $[26,46,47]$, transcript levels increased significantly at $10^{-1}$ and 10 $\mathrm{mg} / \mathrm{l}\left({ }^{*} \mathrm{p}<0.05\right)$, whereas HO-1 transcript levels of $1 \mathrm{mg} / \mathrm{l}$ PtNP-treated cells increased 1.68-fold compared with that of the untreated cells $\left({ }^{* *} \mathrm{p}<0.01\right.$, Fig. 5b). Mitochondrial enzyme, Mn-SOD transcript levels were increased in a concentration-dependent manner from $10^{-1}$ to $10 \mathrm{mg} / \mathrm{l}$ (Fig. 5c). Cytosolic enzyme CuZn-SOD transcript levels were not induced in a concentration-dependent manner, although a statistical analysis indicated that mRNA levels of cells treated with $10^{-1}$ to $10 \mathrm{mg} / 1$ of PtNPs increased significantly compared with that of the untreated control cells $\left({ }^{* *} \mathrm{p}<0.01\right.$ for $1 \mathrm{mg} / \mathrm{l}$; ${ }^{*} \mathrm{p}<0.05$ for $10^{-1}$ and $10 \mathrm{mg} /$ 1; Fig. 5d). Catalase transcript levels were increased significantly at $10^{-1}$ and $1 \mathrm{mg} / \mathrm{l}$ of PtNPs $\left({ }^{* *} \mathrm{p}<0.01\right.$ for $10^{-1}$ $\mathrm{mg} / \mathrm{l} ;{ }^{*} \mathrm{p}<0.05$ for $1 \mathrm{mg} / \mathrm{l}$ ) (Fig. 5e). GPx transcript levels also increased significantly at 1 and $10 \mathrm{mg} / \mathrm{l} \mathrm{PtNP}$-treated cells $\left({ }^{*} \mathrm{p}<0.05\right.$ for $1 \mathrm{mg} / 1 ;{ }^{* *} \mathrm{p}<0.01$ for $10 \mathrm{mg} / \mathrm{l}$; Fig. $\left.5 \mathrm{f}\right)$. Expression levels of most of the antioxidative genes were increased significantly at concentrations between $10^{-1}$ and $10 \mathrm{mg} / \mathrm{l}$ PtNPs. Considering that the cytotoxic effect observed at $10 \mathrm{mg} / \mathrm{l}$ PtNPs and a reduction of the GSH/ GSSG ratio, the hierarchical oxidative stress model does explain the effect of PtNPs in the range of $10^{-1}$ to $10 \mathrm{mg} / \mathrm{l}$. In this model, a lower amount of oxidative stress induces antioxidant enzymes by the antioxidant responsive element (ARE) activated by Nrf2. Involvement of the Nrf2/ARE pathway for anti-oxidant enzyme production by oxidative stress has been supported by various studies $[18,24,27,28]$.

On the other hand, PtNPs treatment at concentrations of $10^{-3} \mathrm{mg} / 1$ and $10^{-2} \mathrm{mg} / 1$ resulted in significant upregulations of gene expressions for GR and Mn-SOD. However, for example, $\mathrm{ZnO}$ NPs at $20 \mathrm{mg} / \mathrm{l}$ caused weak cytotoxicity while several antioxidant enzyme activities and GSH levels were up-regulated. However, when the $\mathrm{NP}$ concentration was reduced to $10 \mathrm{mg} / \mathrm{l}$, such regulatory effects were no longer observed [48]. Other group also reported similar conclusion by using $\mathrm{TiO}_{2}$ NPs [49]. These reports suggest that decrease of NP concentration in a very narrow range results in no change in the antioxidative gene expressions and GSH levels. We reduced PtNPs concentrations to $1 / 1,000$ and $1 / 10,000$ of $10 \mathrm{mg} / 1$, yet the reduction of intracellular ROS and increased GSH level were observed. Therefore, the cellular responses at these extremely low concentrations of PtNPs are less likely to be explained by the hierarchical oxidative stress model. 
(a)

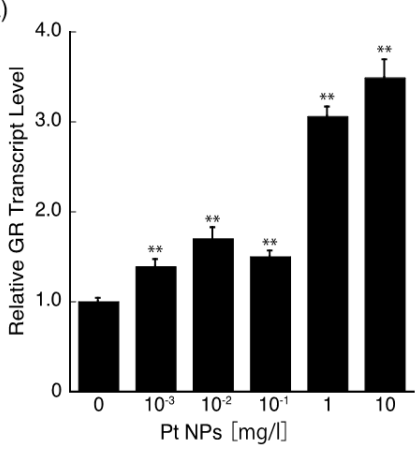

(d)

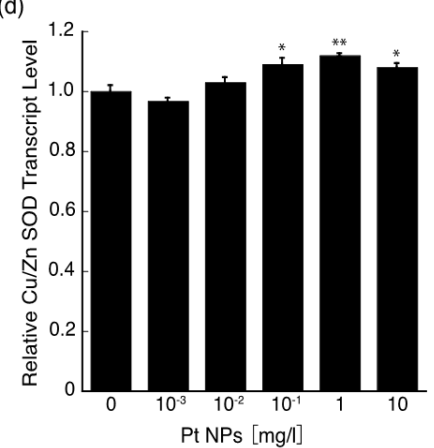

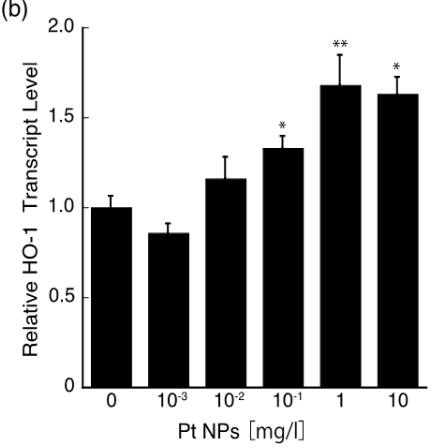

(e)

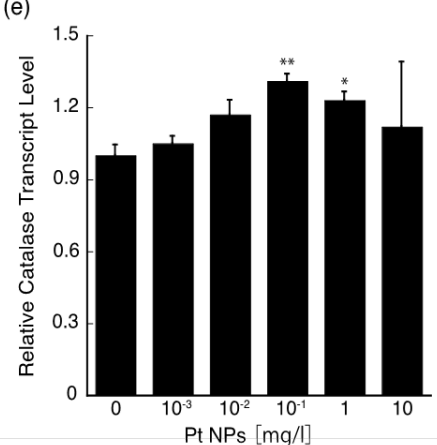

(c)
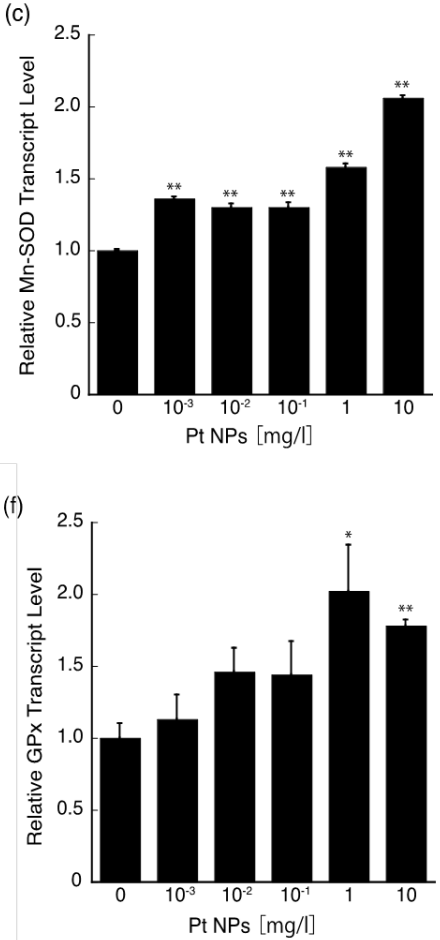

Fig. 5 Effect of PtNPs on levels of mRNAs coding for antioxidative proteins measured by qRT-PCR. L6 cells were seeded in a 60 -mm dish at a density of $1.0 \times 10^{5}$ cells/well and incubated for $24 \mathrm{~h}$. Culture medium was replaced with $5 \mathrm{ml}$ of medium containing PtNPs at concentrations of 0-10 mg/l. After the $2 \mathrm{~h}$ incubation, the cells were used to prepare total RNA for RT-PCR analysis. PCR primer sequences for each target gene are shown in Table 1. The results are displayed as fold induction relative to the control and normalized against GAPDH expression. Asterisks denote significant $\left({ }^{*} \mathrm{P}<0.05,{ }^{* *} \mathrm{P}<0.01\right)$ difference from the untreated control cells.

We observed an increased tendency of LDH leakage in response to increasing PtNP concentrations (up to 10 $\mathrm{mg} / \mathrm{l}$ ), decreased the GSH/GSSG ratio at $10 \mathrm{mg} / \mathrm{l}$, and upregulation of antioxidative enzyme gene expression at $1 \mathrm{mg} / 1$ and $10 \mathrm{mg} / 1 \mathrm{PtNPs}$ accompanied with strong ROS scavenging activity. Other reports supporting the hierarchical oxidative stress model have not demonstrated the correlation that NPs induce intracellular ROS to initiate the activation of antioxidative enzyme gene expression. The model implicates a subsequent ROS scavenging by these enzymes. However, we have not found any report associating upregulation of antioxidative enzyme gene expression with ROS scavenging activity by NPs. Therefore, the reduction of intracellular ROS is assumed the result of direct ROS scavenging activity by PtNPs at $1 \mathrm{mg} / \mathrm{l}$ and $10 \mathrm{mg} / \mathrm{l}$ based on an in vitro study [14]. Although direct ROS scavenging by PtNPs at $10^{-2}$ or $10^{-3} \mathrm{mg} / 1$ is an attractive possibility, it is less likely because the PtNP concentrations are too low. Our group and others have reported that NPs including PtNPs are internalized via pinocytosis, diffusion, and other processes $[14,16,17,36]$. According to reports, internalized PtNPs are estimated to be approximately 8,000 particles per cell when using $2 \mathrm{~nm}$ PtNPs at $10 \mathrm{mg} / \mathrm{l}$; this demonstrates strong ROS scavenging activity when these PtNPs are added to the cells. By simple calculation, the internalized PtNPs will be 8 particles per cell when $10^{-3} \mathrm{mg} / \mathrm{l}$ PtNPs is added to the cells $[14,50]$. Therefore, it is unlikely that such a small number of internalized PtNPs could directly exert strong ROS scavenging ability in the present study.
Taken together, the cellular responses at these extremely low concentrations of PtNPs would suggest alternative mechanisms that are different from the hierarchical oxidation stress model. Intracellular redox regulation systems are very complicated and not fully understood [51].

From our results, one of possible pathways activated by PtNPs at low concentration may be directly or indirectly involved in the GR activation pathway rendering the activation of GSH up-regulatory pathway. However, protein synthesis and enzyme activities are remained to be investigated because the increments of GSH amount, and of GR and Mn-SOD transcript levels by PtNPs treatment were not large and did not show prominent dose dependencies. Another possible pathway is to activate the thioredoxin system, which regulates intracellular redox status through the cascade distinct from either the Nrf2ARE pathway or the GSH/GSSG system [52]. Protein disulfide isomerase, part of a superfamily referred to as the thioredoxin superfamily, regulates the ratio of sulfhydryl residue in many redox-sensitive proteins such as ER oxidoreduction family proteins [53].

It has been known that carbon particles and PM2.5 activate epidermal growth factor receptor and stimulate signal cascades [18,54]. Similarly, AuNPs inhibit I kappa B kinase (IKK) activity by modifying Cys-179 of IKK $\beta$, which is a subunit of IKK kinase complex [55]. As stated above, nanoparticles will participate not only in the induction of oxidative stress but also in the activation of signal cascades to scavenge ROS in cells. Taken together, PtNPs 
may modulate ROS scavenging systems independent of Nrf2-ARE pathway by binding to redox related receptors and/or proteins.

We have studied the antioxidant effects of PtNPs on multicellular organisms, which will provide fundamental information leading to understanding their safety and antioxidant efficacy. It has been reported that the lifespan of $C$. elegans was extended by the SOD/catalase mimetic activities of PtNPs [56]. Moreover, electrochemically reduced water and synthetic PtNPs at ppb concentrations have been shown to scavenge ROS induced by paraquat in the nematode and significantly extend its lifespan [57,58]. Notably, levels of PtNPs contained in electrochemically reduced water, which is safe and approved for human consumption, have resulted in an extension of $C$. elegans lifespan [58].

Present results together with previously published data indicate that PtNPs could exert a critical role in maintaining intercellular redox homeostasis and are expected to be a new type antioxidant distinctively different from existing antioxidants.

\section{Conclusion}

Our results with synthesized PtNPs by the sodium citrate reduction method yielded an average size of $2.2 \mathrm{~nm}$ and were found to be non-toxic to L6 rat skeletal muscle cells based on cell viability and LDH release assays. Moreover, we found that a very low PtNP concentration (i.e., $10^{-2} \mathrm{mg} / \mathrm{l}$ ) scavenged both induced and intrinsic ROS in L6 cells. In the present study, we aimed to clarify the mechanisms involved in this ROS scavenging effect using the hierarchical oxidative stress model as an experimental model. We found that the results obtained from the $10^{-3}-10 \mathrm{mg} / 1 \mathrm{PtNP}$ treatments were in agreement with the hierarchical oxidative stress model. However, the model does not fully explain the ROS scavenging mechanism at $10^{-2} \mathrm{mg} / \mathrm{l} \mathrm{PtNPs}$ and implies an alternative ROS scavenging mechanism.

\section{References}

1 Finkel T., Holbrook N.J. Oxidants, oxidative stress and biology of aging. Nature 2000; 408: 239-247.

2 Buttke T.M., Sandstorm P.A. Oxidative stress as a mediator of apoptosis. Immunol. Today 1994; 15: 7-10.

3 Perry G., Raina A.K., Nunomura A., Wataya T., Sayre L.M., Smith M.A. How important is oxidative damage? Lessons from Alzheimer's disease. Free Radic. Biol. Med. 2000; 28: 831-834.

4 Matsuo M. Aging and oxidative stress resistance in human fibroblasts. J. Clin. Biochem. Nutr. 2004; 35: 63-70.

5 Gius D., Spitz D.R. Redox signaling in cancer biology. Antioxid. Redox Signal. 2006; 8: 1249-1252.

6 Baba S., Osakabe N., Natsume M., Muto Y., Takizawa T., Terao J. Absorption and urinary excretion of (-)-epicatechin after administration of different levels of cocoa powder or (-)-epicatechin in rats. J. Agric. Food Chem. 2001; 49: 6050-6056.

7 Gilgun-Sherki Y., Melamed E., Offen D. Oxidative stress inducedneurodegenerative diseases: the need for antioxidants that penetrate the blood brain barrier. Neuropharmacology 2001; 40: 959-975.

8 Podmore I.D., Griffiths H.R., Herbert K.E., Mistry N., Mistry P., Lunec J. Vitamin C exhibits prooxidant properties. Nature 1998; 392: 559.
9 Kawanishi S., Oikawa S., Murata M. Evaluation for safety of antioxidant chemopreventive agents. Antioxid. Redox Signal. 2005; 7: 1728-1739.

10 Alaaldin M.A., Murphy C.J. Toxicity and cellular uptake of gold nanoparticles: what we have learned so far? J. Nanopart. Res. 2010; 12: 2313-2333.

11 Brust M., Gordillo G.J. Electrocatalytic hydrogen redox chemistry on gold nanoparticles. J. Am. Chem. Soc. 2012; 134: 3318-3321.

12 Kim N.H., Lee M.Y., Park S.J., Choi J.S., Oh M.K., Kim I.S. Auranofin blocks interleukin-6 signalling by inhibiting phosphorylation of JAK1 and STAT3. Immunology 2007; 122: 607-614.

13 Aiuchi T., Nakajo S., Nakaya K. Reducing activity of colloidal platinum nanoparticles for hydrogen peroxide, 2,2-diphenyl1-picrylhydrazyl radical and 2,6-dichlorophenol indophenol. Biol. Pharm. Bull. 2004; 27: 736-738.

14 Hamasaki T., Kashiwagi T., Imada T., Nakamichi N., Aramaki S., Toh K., Morisawa S., Shimakoshi H., Hisaeda Y., Shirahata S. Kinetic analysis of superoxide anion radical-scavenging and hydroxyl radical-scavenging activities of platinum nanoparticles. Langmuir 2008; 24: 7354-7364.

15 Kawasaki H., Yonezawa T., Watanabe T., Arakawa R. Platinum nanoflowers for surface-assisted laser desorption/Ionization mass specrometry of biomolecules. J. Phys. Chem. C. 2007; 111: 16279-16283.

16 Elder A., Yang H., Gwiazda R., Teng X., Thurston S., He H., Oberdörster G. Testing nanomaterials of unknown toxicity: An example based on platinum nanoparticles of different shapes. Adv.Mater. 2007; 19: 3124-3129.

17 Gehrke H., Pelka J., Hartinger C.G., Blank H., Bleimund F., Schneider R., Gerthsen D., Bräse S., Crone M., Türk M., Marko D. Platinum nanoparticles and their cellular uptake and DNA platination at non-cytotoxic concentrations. Arch. Toxicol. 2011; 85: 799-812.

18 Marano F., Hussain S., Lima F.R., Squiban A.B., Boland S. Nanoparticles: molecular targets and cell signaling. Arch. Toxicol. 2011; 85: 733-741.

19 Carlson C., Hussain S.M., Schrand A.M., Braydich-Stolle L.K., Hess K.L., Jones R.L., Schlager J.J. Unique cellular interaction of silver nanoparticles: size-dependent generation of reactive oxygen species. J. Phys. Chem. B. 2008; 112: 13608-13619.

20 Eom H.J., Choi J. Oxidative stress of $\mathrm{CeO}_{2}$ nanoparticles via p38-Nrf-2 signaling pathway in human bronchial epithelial cell, Beas-2B. Toxicol. Lett. 2009; 187: 77-83

21 Patil G., Khan M.I., Patel D.K., Sultana S., Prasad R., Ahmad I. Evaluation of cytotoxic, oxidative stress, proinflammatory and genotoxic responses of micro- and nano-particles of dolomite on human lung epithelial cells A(549). Environ. Toxicol. Pharmacol. 2012; 34: 436-445.

22 Xiao G.G., Wang M., Li N., Loo J.A., Nel A.E. Use of proteomics to demonstrate a hierarchical oxidative stress response to diesel exhaust particle chemicals in a macrophage cell line. J. Bio. Chem. 2003; 278: 50781-50790.

23 Nel A., Xia T., Mädler L., Li N. Toxic potential of materials at the nanolevel. Science 2006; 311: 622-627.

24 Calkins M.J., Johnson D.A., Townsend J.A., Vargas M.R., Dowell J.A., Williamson T.P., Kraft A.D., Lee J.M., Li J., Johnson J.A. The Nrf2/ARE pathway as a potential therapeutic target in neurodegenerative disease. Antioxid. Redox Signal. 2009; 11: 497-508.

25 Sen C.K., Rahkila P., Hänninen O. Glutathione metabolism in skeletal muscle derived cells of the L6 line. Acta. Physiol. Scand. 1993; 148: 21-26.

26 Mann G.E., Niehueser-Saran J., Watson A., Gao L., Ishii T., de Winter P., Siow R.C. Nrf2/ARE regulated antioxidant gene expression in endothelial and smooth muscle cells in oxidative stress: implications for atherosclerosis and preeclampsia. Sheng. Li. Xue. Bao. 2007; 59: 117-127.

27 Balogun E., Hoque M., Gong P., Killeen E., Green C.J, Foresti R., Alam J., Motterlini R. Curcumin activates the haem oxygenase-1 gene via regulation of $\mathrm{Nrf} 2$ and the antioxidant-responsive element. Biochem. J. 2003; 371: 887-895.

28 Lee J.M., Johnson J.A., An important role of Nrf2-ARE pathway in the cellular defense mechanism. J. Biochem. Mol. Biol. 2004; 37: 139-143.

29 Kajita M., Hikosaka K., Iitsuka M., Kanayama A., Toshima N., 
Miyamoto Y. Platinum nanoparticle is a useful scavenger of superoxide anion and hydrogen peroxide. Free Radic. Res. 2007; 41: 615-626

30 Victor E.G., Silveira P.C., Possato J.C., da Rosa G.L., Munari U.B., de Souza C.T., Pinho R.A., da Silva L., Streck E.L., Paula M.M. Pulsed ultrasound associated with gold nanoparticle gel reduces oxidative stress parameters and expression of pro-inflammatory molecules in an animal model of muscle injury. J. Nanobiotechnol. $2012 ; 12 ; 11$

31 Turkevich J., Miner R.S., Babenkova L. Further studies on the synthesis of finely divided platinum. J. Phys. Chem. 1986; 90: 4765-4767.

32 Fischer D., Li Y., Ahlemeyer B., Krieglstein J., Kissel T. In vitro cytotoxicity testing of polycations: influence of polymer structure on cell viability and hemolysis. Biomaterials 2003; 24: 1121-1131.

33 Hissin P.J., Hilf R. A fluorometric method for determination of oxidized and reduced glutathione in tissues. Anal. Biochem. 1976; $74:$ : 214-226.

34 Chen H., Zhou L., Lin C.Y., Beattie M.C., Liu J., Zirkin BR. Effect of glutathione redox state on Leydig cell susceptibility to acute oxidative stress. Mol. Cell Endocrinol. 2010; 323: 147-154.

35 Hirn S., Semmler-Behnke M.,Schleh C., Wenk A., Lipka J., Schäffler M., Takenaka S., Möller W., Schmid G., Simon U., Kreyling WG. Particle size-dependent and surface charge-dependent biodistribution of gold nanoparticles after intravenous administration. Eur. J. Pharm. Biopharm. 2011; 77: 407-416.

36 Asharani P.V., Xinyi N., Hande M.P., Valiyaveettil S. DNA damage and $\mathrm{p} 53$-mediated growth arrest in human cells treated with platinum nanoparticles. Nanomedicine 2010; 5: 51-64.

37 Sharma V., Anderson D., Dhawan A. Zinc oxide nanoparticles induce oxidative DNA damage and ROS-triggered mitochondria mediated apoptosis in human liver cells (HepG2). Apoptosis 2012; 17: 852870.

38 Pujalté I., Passagne I., Brouillaud B., Tréguer M., Durand E., Ohayon-Courtès C., L'Azou B. Cytotoxicity and oxidative stress induced by different metallic nanoparticles on human kidney cells. Part. Fibre. Toxicol. 2011; 8: 10.

39 Lewinski N., Colvin V., Drezek R. Cytotoxicity of nanoparticles. Small 2008; 4: 26-49.

40 Pelka J., Gehrke H., Esselen M., Türk M., Crone M., Bräse S., Muller T., Blank H., Send W., Zibat V., Brenner P., Schneider R., Gerthsen D., Marko D. Cellular uptake of platinum nanoparticles in human colon carcinoma cells and their impact on cellular redox systems and DNA integrity. Chem. Res. Toxicol. 2009; 22: 649-659.

41 Yoshihisa Y., Zhao Q.L., Hassan M.A., Wei Z.L., Furuichi M., Miyamoto Y., Kondo T., Shimizu T. SOD/catalase mimetic platinum nanoparticles inhibit heat-induces apoptosis in human lymphoma U937 and HH cells. Free Radic. Res. 2011; 45: 326-335.

42 Maeda H., Fukuyasu Y., Yoshida S., Fukuda K., Saeki K., Matsuno H., Yamauchi Y., Yoshida K., Hirata K., Miyamoto K. Fluorescent probes for hydrogen peroxide based on a non-oxidative mechanism. Angew. Chem. Int. Ed. Engl. 2004; 43: 2389-2391.

43 Long T.C., Tajuba J., Sama P., Saleh N., Swartz C., Parker J., Hester S., Lowry GV., Veronesi B. Nanosize titanium dioxide stimulates reactive oxygen species in brain microglia and damages neurons in vitro. Environ. Health Perspect 2007; 115: 1631-1637.

44 Armstrong J.S., Steinauer K.K., Hornung B., Irish J.M., Lecane P., Birrell G.W., Peehl D.M., Knox S.J. Role of glutathione depletion and reactive oxygen species generation in apoptotic signaling in a human B lymphoma cell line. Nature 2002; 9: 252-263.

45 Habib G.M., Shi ZZ., Lieberman MW. Glutathione protects cells against arsenite-induced toxicity. Free Radic. Biol. Med. 2007; 42: 191-201

46 Keyse SM., Tyrrell RM., Heme oxygenase is the major 32-kDa stress protein induced in human skin fibroblasts by UVA radiation, hydrogen peroxide, and sodium arsenite. Proc. Natl. Acad. Sci. US A.1989: 86: 99-103.

47 Valko M., Leibfritz D., Moncol J., Cronin MT., Mazur M., Telser J. Free radicals and antioxidants in normal physiological functions and human disease. Int. J. Biochem. Cell Biol. 2007; 39: 44-84.

48 Lee SH., Pie JE., Kim YR., Lee HR., Son SW., Kim MK. Effects of zinc oxide nanoparticles on gene expression profile in human keratinocytes. Mol. Cell. Toxicol. 2012; 8: 113-118.
Cui Y., Gong X., Duan Y., Li N., Hu R., Liu H., Hong M., Zhou M.,
Wang L., Wang H., Hong F. Hepatocyte apoptosis and its molecular mechanisms in mice caused by titanium dioxide nanoparticles. $J$. Hazard. Mater. 2010; 183: 874-880.

50 Kinjo T., Ye J., Yan H., Hamasaki T., Nakanishi H., Toh K., Nakamichi N., Kabayama S., Teruya K., Shirahata S. Suppressive effects of electrochemically reduced water on matrix metalloproteinase- 2 activities and in vitro invasion of human fibrosarcoma HT1080 cells. Cytotechnology 2012; 64: 357-371.

51 Shirahata S., Hamasaki. Advanced research on the health-benefit of reduced water. Trends Food Sci. Technol. 2012; 23: 124-131.

52 Circu M.L., Aw T.Y. Reactive oxygen species, cellular redox systems, and apoptosis. Free. Radic. Biol. Med. 2010; 48: 749-762.

53 Laurindo F.R.M., Pescatore L.A., Fernandes D de C. Protein disulfide isomerase in redox cell signaling and homeostasis. Free Radic.Biol. Med. 2012: 1954-1969.

54 Stefaan J.S., Pilar R.G., José-María M., Wolfgang J.P., Stefaan C.D.S., Kevin B. Cellular toxicity of inorganic nanoparticles: common aspects and guidelines for improved nanotoxicity evaluation. Nano Today 2011; 6: 446-465.

55 Jeon K.I., Byun M.S., Jue D.M. Gold compound auranofin inhibits IkappaB kinase (IKK) by modifying Cys-179 of IKKbeta subunit. Exp. Mol. Med. 2003; 35: 61-66

56 Melov S., Ravenscroft J., Malik S., Gill M.S., Walker D.W., Clayton P.E., Wallace D.C., Malfroy B., Doctrow S.R., Lithgow G.J. Extension of life-span with superoxide dismutase/catalase mimetics. Science 2000; 289: 1567-1569.

57 Yan H., Tian H., Kinojo T., Hmasaki T. Tomimatsu K., Nakamichi N., Teruya K., Kabayama S., Shirahata S. Extension of the lifespan of Caenorhabditis elegans by the use of electrolyzed reduced water. Biosci. Biotechnol. Biochem. 2010; 74: 2011-2015.

58 Yan H., Kinjo T., Tian H., Hamasaki T., Teruya K., Kabayama S., Shirahata S. Mechanism of the lifespan extension of Caenorhabditis elegans by electrolyzed reduced water - participation of Pt nanoparticles. Biosci. Biotechnol. Biochem. 2011: 75: 1295-1299.

59 Shimada H., Ochi T., Imasato A., Morizane Y., Hori M., Ozaki H., Shinjo K. Gene expression profiling and functional assays of activated hepatic stellate cells suggest that myocardin has a role in activation. Liver Int. 2010; 30: 42-54

60 Minelli A., Conte C., Grottelli S., Bellezza I., Cacciatore I., Bolaños JP. Cyclo(His-Pro) promotes cytoprotection by activating Nrf2-mediated up-regulation of antioxidant defence. J. Cell. Mol. Med. 2009; 13: 1149-1161.

61 Sartori A., Garay-Malpartida H.M., Forni M.F., Schumacher R.I., Dutra F., Sogayar M.C., Bechara E.J. Aminoacetone, a putative endogenous source of methylglyoxal, causes oxidative stress and death to insulin-producing RINm5f cells. Chem. Res. Toxicol. 2008; 21: 1841-1850.

62 Ramesh E., Jayakumar T., Elanchezhian R., Sakthivel M., Geraldine P., Thomas PA. Green tea catechins, alleviate hepatic lipidemic-oxidative injury in Wistar rats fed an atherogenic diet. Chem. Biol. Interact. 2009; 180: 10-19.

63 Hassimotto N.M., Lajolo F.M. Antioxidant status in rats after long-term intake of anthocyanins and ellagitannins from blackberries J. Sci. Food Agric. 2011; 91: 523-531.

64 Vesentini N., Barsanti C., Martino A., Kusmic C., Ripoli A., Rossi A.M., L'Abbate A. Selection of reference genes in different myocardial regions of an in vivo ischemia/ reperfusion rat model for normalization of antioxidant gene expression, BMC Res. Notes 2012; 5: 124

65 Chen Y., Zhu X., Zhao S., Xing H., Li Y. Hemin, a heme oxygenase-1 inducer, improves aortic endothelial dysfunction in insulin resistant rats. Chin. Med. J. 2008; 121: 241-247.

Copyright:(c) 2013 H. Nakanishi et al. This is an open-access article distributed under the terms of the Creative Commons Attribution License, which permits unrestricted use, distribution, and reproduction in any medium, provided the original author and source are credited. 